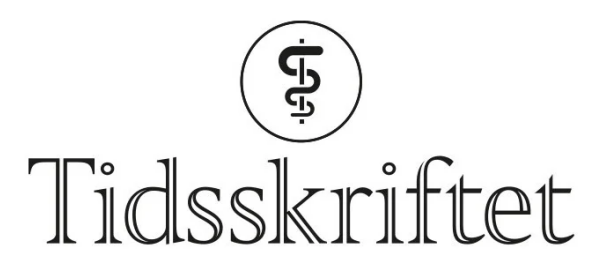

DEN NORSKE LEGEFORENING

\title{
Kjære kollega
}

\section{MINILEDER}

\section{ARE BREAN}

Sjefredaktør

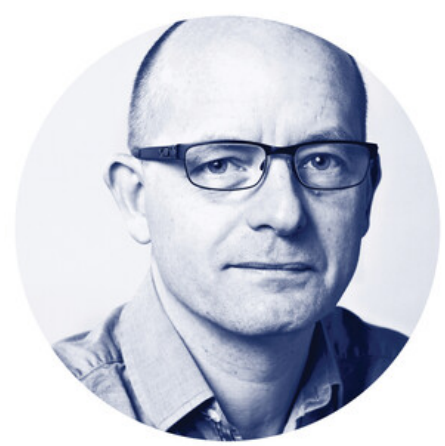

2021 skulle bli året da vi kunne se tilbake på pandemien. Slik ble det ikke. Belastningen er fortsatt høy i store deler av helsevesenet, og usikkerheten er stor for hva vinteren 2022 vil bringe. Likevel skal vi nok en gang feire barnet i krybben, og med det feire håpet, lyset og livet, slik vi har gjort på våre vintermørke breddegrader siden førkristen tid. Også i 2022 skal norske leger gi håp og liv, omsorg, trøst og lindring. Som i fjor, er det derfor også denne julen verdt å minne om formuleringen i Verdens legeforenings universelle legeed: "Jeg vil ivareta min egen helse, mitt velvære og mine evner, for å kunne gi omsorg av den høyeste standard». Ta deg tid til å ta vare på deg selv og dine nærmeste i høytiden vi snart går inn i. Dine pasienter fortjener det. Riktig god jul!

Publisert: 13. desember 2021. Tidsskr Nor Legeforen. DOI: 10.4045/tidsskr.21.18.01

(C) Tidsskrift for Den norske legeforening 2023. Lastet ned fra tidsskriftet.no 26. april 2023. 